\title{
Clustering as a way to ensure the competitiveness of Russian regions: comprehension of current state and development prospects
}

\author{
Oleg Inshakov \\ Volgograd State University, \\ Scientific Research Institute of Social and Economic \\ Development of the Region \\ Volgograd, Russia \\ president@volsu.ru
}

\author{
Elena Inshakova \\ Volgograd State University, \\ Institute of Economics and Finance \\ Volgograd, Russia \\ inshakovaei@volsu.ru
}

\author{
Svetlana Beloglazova \\ Volgograd State University, \\ Institute of Economics and Finance \\ Volgograd, Russia \\ interec@volsu.ru
}

\begin{abstract}
This article substantiates the necessity of systemic formation of clusters in the regions of the Russian Federation, which promote realization of the innovative potential of regional economic systems and strengthen their competitiveness by achieving the economic and social synergetic effect of developing all forms of factor capital and increasing the quality of life on the territory of cluster functioning and influencing. The authors have analyzed the dynamics of the Russian clusterization process for the period 2008-2017, described its current state and made conclusions about the "catch-up" nature of the processes of clustering in the Russian economy, slow rates of its development, asymmetric and asynchronous engagement of regions, and their inertness in applying the cluster policy. The assessment of the possibilities and justification of the prospective directions for the formation of clusters in the regions of the Southern Federal District have been carried out in the paper.
\end{abstract}

Keywords-innovative modernization of economy, cluster, clustering, cluster policy, clusterization process, smart specialization of a region

\section{INTRODUCTION}

Russian economy innovative modernization, being an imperative of its contemporary development, actualizes the systemic implementation of cluster policy and the formation of clusters in Russian regions. In this article, clusters are defined as the sustained cross-industry groups of independent enterprises (firms) aimed at producing common final good or service, which are compactly localized in compliance with their scale and function. Clusters' development, functioning and operation are directed to the effective realization of the innovative potential of regional economic systems and strengthening their competitiveness.
The cluster approach involves the implementing by a target group of firms interdependent measures and projects on effective resource mobilizing and production factors using that are based on their relationship stability and security, and cost minimization while maintaining sufficient quality of mutually supplied goods and services. This results in the economic and social synergetic effect of developing all forms of factor capital and increasing the quality of life on the territory of a cluster's functioning and influencing.

The comprehensive development of clusters in the Russian economy, which is in urgent need of modernization, remains one of the issues of high importance, since any significant progress and acceleration of clustering processes in the regions of Russia has not yet been achieved. Under these conditions, the assessment of the potential for clusters construction in the regions of Russia as a factor determining the status, opportunities, and ways of innovative modernization and growth horizons of regional economic systems is becoming a topical matter for economic theory and practice.

\section{MATERIALS AND METHODS}

The objectives of the study were solved on the basis of applying methodology of systemic and evolutionary approaches to the analysis of such complex objects as clusters in the regional economies of the Russian Federation taking into consideration the level of their development, occasionally passive or opportunistic behavior of regional governments and businesses, and impact of the unfavorable environment.

The synthesis of structural and functional, temporal and spatial, aspectual and comparative, statistical and documentary 
analysis has been realized in the research work. The experts' and authors' quantitative and qualitative evaluation of dynamics and contemporary state of Russian economy clustering allowed drawing conclusions about the necessity of implementing the multilevel clusterization policy in the regional development strategies.

\section{RESULTS AND DISCUSSION}

The concept of clusters as drivers of economic development based on creating new knowledge, accelerating innovation and applying high technologies for the industrial production of progressive goods had received public recognition a long time ago. The experts of the World Economic Forum in collaboration with the scientists from the Columbia University (USA) have confirmed the existence of direct dependence between competitiveness, innovation potential and the level of cluster development in an economy. Within the framework of evolutionary economic theory, Russian scientists interpret clusters as a way for firms to organize their own environment to improve the efficiency of functioning due to their sustained localized cooperation and external economies [1]. Thus, clusters are recognized not only as drivers of development, but also as guarantors of its sustainability, ensuring successful competition of firms by organizing their market environment.

\section{A. Parameters of dynamics of clustering processes in the Russian Federation economy}

The calculations based on the statistical and analytical data indicate that the policy of both traditional and innovative clustering in the Russian Federation has not gained the desired success, and cluster development indicators do not demonstrate a positive stable trend in the period of 2008-2017 (Table I) [2].

Comparative analysis of data on the number of clusters created and functioning in Russia and abroad reflects the "catch-up" nature of the processes of clustering in the Russian economy, which are characterized by slow rates of development, asymmetric and asynchronous engagement of regions, and inertness in applying the cluster policy. According to data provided by the website of the Russian cluster observatory (http://cluster.hse.ru) of the National Research University Higher School of Economics (HSE University) 113 clusters were created in Russia during the period 1999 - 2017. These include pilot innovative territorial and industrial clusters, as well as clusters supported by cluster development centers. However, the listed clusters differ significantly in terms of development level: only $8 \%$ of them are mature, about $12.4 \%$ are developing ones, others are considered as emerging. At the same time, according to the Russian Association of Clusters and Technology Parks, there are 130 industrial clusters in 56 Russian regions [3, p. 18].

In contrast, there are 477 clusters in Germany according to data published on the web portal Clusterplattform Deutschland (http://www.clusterplattform.de), a joint project of the Federal Ministry of Economics and Energy and the Federal Ministry of Education and Research. What is more, there are 103 clusters only on the territory of the State Baden-Württemberg. It is quite natural that Germany, being ranked $4^{\text {th }}$ out of 138 countries by the level of cluster development, had the $4^{\text {th }}-5^{\text {th }}$ rank (the same as the Netherlands) in the ranking of global competitiveness of 2016-2017 [2].

The above data on the results of clustering of the Russian economy demonstrate the inconsistency and even contrariety of the information available in free access. Although this information is sufficient to conclude that our country fails to keep pace with the world leaders in terms of national economy clustering.

The current situation became a natural consequence of the economic policy miscalculations and the continuing institutional uncertainty of clustering processes [4], delays in their government support, the lack of financial resources, the insufficient activity of private investors, the slow implementation of progressive structural changes in the economy, and the influence of unfavorable external environment.

TABLE I. ASSESSMENT OF THE RUSSIAN ECONOMY CLUSTERIZATION PERFORMANCE BASED ON THE RANKING OF COUNTRIES ON THE GLOBAL COMPETITIVENESS INDEX (GCI), $2008-2017$

\begin{tabular}{|c|c|c|c|c|c|c|c|}
\hline $\begin{array}{c}\text { Estimated } \\
\text { periods }\end{array}$ & $\begin{array}{l}\text { Rank of the } \\
\text { Russian } \\
\text { Federation in } \\
\text { the ranking by } \\
\text { the GCI score }\end{array}$ & $\begin{array}{c}\text { Rank of the } \\
\text { Russian Federation } \\
\text { in the ranking by } \\
\text { the cluster } \\
\text { development }(\mathrm{m})\end{array}$ & $\begin{array}{c}\text { Number of } \\
\text { countries in } \\
\text { the ranking }(n)\end{array}$ & $\begin{array}{c}\text { Assessment of } \\
\text { the rank of } \\
\text { the Russian } \\
\text { Federation in } \\
\text { the ranking } \\
(\mathrm{m} / \mathrm{n})\end{array}$ & $\begin{array}{l}\text { Assessment of the } \\
\text { Russian economy } \\
\text { clusterization } \\
\text { performance } \\
\text { (max } 7 \text { points) }\end{array}$ & $\begin{array}{c}\text { Difference } \\
\text { between the } \\
\text { rank of the RF } \\
\text { and last rank } \\
\text { in the ranking } \\
(\mathrm{n}-\mathrm{m})\end{array}$ & $\begin{array}{c}\text { The general } \\
\text { assessment of } \\
\text { a trend of the } \\
\text { Russian } \\
\text { Federation } \\
\text { rank } \\
(m / n)(n-m)\end{array}$ \\
\hline $2008-2009$ & 51 & 96 & 134 & 0.7059 & 3.0 & 38 & 26.8242 \\
\hline $2009-2010$ & 63 & 90 & 133 & 0.6767 & - & 43 & 29.0981 \\
\hline $2010-2011$ & 63 & 87 & 139 & 0.6259 & - & 52 & 32.5468 \\
\hline 2011-2012 & 66 & 92 & 142 & 0.6479 & 3.2 & 50 & 32.3950 \\
\hline 2012-2013 & 67 & 114 & 144 & 0.7917 & 3.0 & 30 & 23.7510 \\
\hline 2013-2014 & 64 & 124 & 148 & 0.8378 & 3.1 & 24 & 20.1072 \\
\hline $2014-2015$ & 53 & 118 & 144 & 0.8194 & 3.1 & 26 & 21.3044 \\
\hline $2015-2016$ & 45 & 110 & 140 & 0.7857 & 3.1 & 30 & 23.5710 \\
\hline $2016-2017$ & 43 & 95 & 138 & 0.6884 & 3.4 & 43 & 29.6012 \\
\hline
\end{tabular}

Significant differentiation of the innovative and industrial potentials, of development levels of the basic and supporting elements of regional innovation systems, the institutional and organizational basis for clustering (considered as a strategic 
direction for innovation and industrial policy in the Russian regions), and involvement in innovative modernization of regional economic systems should also be calculated as negative factors for accelerating the clustering processes.

The data provided by the researchers of the HSE University back up this conclusion and show the significant difference between the Russian regions in terms of the level and various aspects of innovative development, and the factors that affect them. As to the HSE University's ranking of innovative regions of Russia published in 2017 [5], the value of the Russian regional innovation index (RRI) in 2015 for a region at the top of the ranking was 3.5 times bigger than the value for a region with the lowest rank.

The regions of the Southern Federal District (hereinafter the SFD) analyzed in this study - the Krasnodar Territory, the Rostov Region, the Volgograd Region and the Astrakhan Region - belong to the $3^{\text {rd }}$ group (out of 4 ) with the following ranks: 33, 26, 39 and 48 (out of 85). Wherein, the state of Volgograd Region $\left(39^{\text {th }}\right.$ place) in the ranking on the value of the composite innovation index (0.334) among all Russian regions has deteriorated by 7 positions in 2015 compared to 2014 (0.363) [5, c. 146-147].

The situation in the Volgograd Region is more pessimistic in the ranking of innovative Russian regions by the Association of Innovative Regions of Russia [6], in which Volgograd Region has taken the $51^{\text {st }}$ place with the value of the innovation development index -0.33 (86.1\% of the average index value of the regions of Russia). As a result, it joined the most numerous group of "medium-weak innovators", which includes 28 regions of the Russian Federation. The region's position in the sub-ranking "Scientific Research and Development" was 33, in the sub-ranking "Innovation activity" - 47, and in the sub-ranking "Innovative activity of the region" - 65 [6, c. 12-15, 24-29].

This is the logical result of the insufficient development of innovative infrastructure in the Volgograd Region and in the SFD as a whole. This statement is confirmed by statistical data on the number of objects of scientific and technological infrastructure in the Volgograd Region in comparison with the other regions of the SFD and in the Russian Federation [7]. There are 47 centers for the collective use of scientific equipment in the SFD out of 580 centers $(8.1 \%)$ functioning in the Russian Federation, and only 8 unique research facilities out of 344 (2.3\%). In the Volgograd Region there are 4 centers for collective use, but there are no unique research facilities. In comparison, the Rostov Region accounts for $43 \%$ of all centers for the collective use and $38 \%$ of the unique research facilities of the SFD's scientific and technological infrastructure. None of the 12 Russian nanotechnology centers established by the JSC RUSNANO is located in the Southern Federal District.

This negatively affects the development of nanoindustry in the regions of the South of Russia, since such centers are significant elements of the nanoindustry infrastructure functioning that are oriented towards providing the full cycle of services for the start-ups' emergence in nanotechnology sphere. They become the interested contributors in the process of nanotechnology clusters formation, and enforce the technological and economic progress in the constituent entities of the Russian Federation.

All this speaks for the strategic need to strengthen the links between science, education and production, as well as for the urgent activation of all regional innovation system's contributors in applying existing tools to support innovation activities.

Such weakness of the institutional and organizational basis for clustering in some Russian regions is a result of the unwillingness or unreadiness to implement prospective "bottom up" cluster initiatives. The authorities and the business community normally expect "top down" decisions on identifying and approving regional specialization directions, and they are not ready to discard these stereotypes.

Based on the HSE University researchers' methodology [5], the qualitative assessment of the institutional and organizational basis for implementing the innovation policy in the Russian regions is possible, which involves the use of the following indicators (Table II):

- Whether there is a strategy (or concept) of innovation development (innovation strategy) and/ or a special part in the regional development strategy concerning innovative development (innovation support) of the region (1).

- Whether there are designated zones (territories) of priority development of innovation activities in the territorial planning schemes, as well as in their justifying documents (2).

- Whether there is a specific legislative act that specifies the main principles, directions and measures of the state support of regional innovation activities (3).

- Whether there is a specific program or a set of measures of state support for the development of innovation, innovation activities, or subjects of innovation activities (4).

- Whether there are specialized coordination (advisory) bodies on innovation policy (support of innovation activities) in the structure of the highest official's office or supreme executive body of State authority of the constituent entity of the Russian Federation (5).

- Whether there are specialized regional development institutes (funds, agencies, development corporations, etc.) supporting innovation subjects and/ or implementing innovative projects (6).

TABLE II. ASSESSMENT OF THE INSTITUTIONAL AND ORGANIZATIONAL BASIS FOR IMPLEMENTATION OF CLUSTER POLICY IN THE SOUTHERN FEDERAL DISTRICT REGIONS, 2016

\begin{tabular}{|l|c|c|c|c|c|c|}
\hline \multirow{2}{*}{\multicolumn{1}{|c|}{ SFD regions }} & \multicolumn{7}{|c|}{ Indicators } \\
\cline { 2 - 8 } & $(\mathbf{1})$ & $\mathbf{( 2 )}$ & $\mathbf{( 3 )}$ & $\mathbf{( 4 )}$ & $\mathbf{( 5 )}$ & $\mathbf{( 6 )}$ \\
\hline Krasnodar Territory & - & - & + & + & + & + \\
\hline Rostov Region & + & - & + & + & - & - \\
\hline Volgograd Region & - & + & + & + & + & + \\
\hline Astrakhan Region & - & + & - & + & + & - \\
\hline
\end{tabular}


It is notable that even in the Volgograd Region, where the process of institutionalizing the innovative economic development has been launched quite a long time ago (the region has been ranked the $7^{\text {th }}$ out of all the Russian Federation regions for regulatory and legal framework of the innovation policy, the $20^{\text {th }}-$ for organizational support for the innovation policy implementation, and the $37^{\text {th }}-$ for budget expenditures on science and innovation) [5, p. 146], clustering is not singled out as an independent strategic direction of the industrial and innovation regional policy, the formation of clusters is in its initial stage and there are only emerging clusters in the region.

\section{B. Opportunities and trends of cluster formation in the Southern Federal District regions}

In order to evaluate the opportunities for cluster formation in the regions of the Southern Federal District, a system of 20 indicators (16 baseline indicators and 4 outcome ones) characterizing the regional production, scientific, technological and educational potential, the level of regional organizational development, as well as the cluster performance has been worked out as a part of the study.

Subsequently the rationing of these indicators was carried out in order to ensure comparability of data. The composite indicators were calculated on the basis of the EXIS (Exploratory Approach to Innovation Scoreboards) methodology and the HSE University methodology applied in the calculation of the Russian regional innovation index.

The research conducted in the study allowed identifying the regions with the most favorable conditions for the cluster policies implementation and the regions with weaker cluster development opportunities for both the individual indicators and the composite indexes of the baseline and outcome indicators.

According to the results of the study, the Rostov Region and the Krasnodar Territory have the best conditions formed for the implementing the cluster policy, the Volgograd Region has nearly the same rank as Krasnodar Territory for this type of indicators, while the Astrakhan Region has a significantly lower potential for the formation and development of clusters.

Determination of options for clusters development in the Southern Federal District was carried out on the basis of identifying the features of its economic specialization. For the quantitative measuring the economic specialization of a region the following coefficients are traditionally used: coefficient of localization, coefficient of per capita output of a particular industry, and coefficient of regional specialization in the production of particular industry products. The findings of the study show that all these three ratios turned to have similar values. The $3^{\text {rd }}$ coefficient - regional specialization on a particular industry (specialization ratio) - will be examined more precisely below.

To qualify an industry as a specialized one, it is necessary to determine the threshold value of the specialization ratio. The spread of its threshold values used in the specialized literature is significant and varies from 0.8 to 2.0 [8, p. 38]. However, most researchers continue to be of the view that clusters can be created in the industries with the specialization ratio equal to or exceeding $1[9, \mathrm{p} .46]$.

The data in the Table III [10] show that such industries as agriculture, construction, manufacturing, and the tertiary industries (hotel and restaurant business, transport and educational services, communications services, health care, others social and public services, public administration and military security, social insurance) have the highest specialization ratio in the Southern Federal District. The value of specialization ratio in each of the industries mentioned above exceeds 1 , therefore their clusterization potential is sufficiently high.

The specialization ratio of the Volgograd Region demonstrates its highest values for agriculture, forestry, hunting, fishing, fish farming; construction; manufacturing and education.

TABLE III. ASSESSMENT OF SPECIALIZATION LEVEL OF THE SFD REGIONS, 2016

\begin{tabular}{|c|c|c|c|c|c|}
\hline Industry & SFD & Krasnodar Territory & Astrakhan Region & Volgograd Region & Rostov Region \\
\hline Agriculture, hunting and forestry & 2.46 & 2.38 & 1.44 & 2.54 & 2.62 \\
\hline Fishing, fish farming & 0.33 & 0.33 & 1.33 & 0.00 & 0.33 \\
\hline Mining & 0.30 & 0.05 & 2.24 & 0.46 & 0.09 \\
\hline Manufacturing & 0.90 & 0.75 & 0.25 & 1.37 & 1.05 \\
\hline $\begin{array}{l}\text { Production and distribution of electricity, gas } \\
\text { and water }\end{array}$ & 0.86 & 0.69 & 0.86 & 0.61 & 1.31 \\
\hline Construction & 1.46 & 1.58 & 1.48 & 1.48 & 1.33 \\
\hline $\begin{array}{l}\text { Wholesale and retail trade, repair of motor } \\
\text { vehicles, motorcycles, and household goods }\end{array}$ & 0.92 & 0.94 & 0.68 & 0.78 & 1.04 \\
\hline Hotels and restaurants & 1.73 & 2.64 & 1.36 & 0.64 & 1.18 \\
\hline Transport and communications & 1.30 & 1.76 & 0.99 & 0.81 & 0.96 \\
\hline Financial activity & 0.40 & 0.60 & 0.60 & 0.40 & 0.40 \\
\hline $\begin{array}{l}\text { Real estate operations, renting and provision of } \\
\text { services }\end{array}$ & 0.70 & 0.69 & 0.72 & 0.67 & 0.72 \\
\hline $\begin{array}{l}\text { Public administration and military security } \\
\text { provision, social insurance }\end{array}$ & 1.04 & 0.88 & 1.48 & 1.08 & 1.04 \\
\hline Education & 1.13 & 1.06 & 1.06 & 1.16 & 1.16 \\
\hline Health care and provision of social services & 1.12 & 1.15 & 1.17 & 1.00 & 1.15 \\
\hline $\begin{array}{l}\text { Other utilities, social and personal services } \\
\text { provision }\end{array}$ & 1.20 & 1.60 & 0.73 & 0.87 & 0.87 \\
\hline
\end{tabular}


According to the Volgograd territorial body of the Federal State Statistics Service, the share of organizations in the above-mentioned industries accounts for $24.5 \%$ of all organizations in the region as of January 1, 2018 [11]. It is important to emphasize the high proportion of industrial activities in the Volgograd regional economic pattern. In the region there are 425 large and medium-sized enterprises carrying out industrial activities (191 enterprises of extraction and energy complex and 234 manufacturing enterprises). The number of employees at industrial enterprises in the Volgograd Region amounts to $18.3 \%$ of the total working population [12]. The region is the only Russian producer of 11 types of industrial products, including specific types of bearings, sulfurous anhydride, polyurethane filaments, and gas pipes.

Of the strategic importance for the Volgograd Region are 6 innovative scientific and educational clusters based on two flagship universities, two specialized universities, two higher education academies, specialized technical schools and vocational education institutions of industrial-technological, socio-economic, medical-pharmaceutical, agrarian, law enforcement, physical culture and sports profiles. The formation of these clusters ensures more efficient specialization training, increasing number of researches and practical application of the findings.

Development of the education system in the Volgograd Region requires special attention for a long time. According to the Human Development Report 2017, containing data for the year 2015 and earlier years [13, p. 275-279, 281], the Volgograd Region has been ranked only $72^{\text {nd }}$ out of 85 regions on the education index (the component of the human development index) with the value 0.926 in 2015 (0.913 in 2014, 0.918 in 2013, 0.896 in 2012, 0.906 in 2011, 0.893 in 2010). At the same time, on the longevity index value $(0.783)$ the Volgograd Region's rank was $22^{\text {nd }}$ in 2015 (0.777 in 2014, 0.774 in 2012, 0.775 in 2012, 0.742 in 2010, and 0.731 in 2010). Thus, the position of the region by education is much worse than the position on life expectancy. This fact negatively affects the transition of Volgograd Region to socioeconomic development on an innovative basis.

Consequently, implementation of the strategy for creating key government-supported universities, restructuring institutions of secondary vocational education, their modernization and significant support from the regional executive authorities is particularly relevant.

It is the innovative scientific and educational clusters that play a key role in development of the regional strategy of "smart specialization". Since smart specialization is not a strategy to be imposed "top-down", its implementation ensures research centers, universities and business structures involvement in collaboration on identifying the advanced areas of regional specialization, needs, strengths and available opportunities of a region [14, p. 12-14].

However, the low level of information accessibility of innovation sector, insufficient usage of advanced information technologies caused by the lack of information about new technologies and potential markets for the knowledgeintensive products, venture capital investments hamper the formation and effective functioning of clusters in the Volgograd Region. The Volgograd Region ranks $81^{\text {st }}$ out of all Russian regions by the share of organizations with access to the Internet with a maximum data transmission speed of 256 Kbps and more in the total number of organizations, and $66^{\text {th }}$ by the information society development level [5, p. 146-147].

Inadequate state support for the formation of new and innovative enterprises, insufficient financing for innovation and lack of its sources [15], small number of platforms for investors with developed business infrastructure, complexity of finding partners for cooperation and collaboration on implementing cluster projects determine the low efficiency of regional economy clustering processes. It is little wonder that Volgograd Region is ranked $59^{\text {th }}$ by innovative activity of organizations.

Strengthening clusterization potential in the region requires expanding support programs for small innovative enterprises, stimulating production application of the intellectual activities results, and increasing the use of new information technologies.

In general, the promising industries for cluster development in the regions of the Southern Federal District are as follows:

The Krasnodar Territory: transport and logistics, tourist clusters, fuel and energy, agro-industrial clusters, light manufacturing cluster (production of clothing, footwear and accessories) and construction cluster.

The Astrakhan region: agro-industrial, fishing, shipbuilding clusters, engineering and technological cluster in the fuel and energy complex, construction cluster.

The Volgograd Region: agro-industrial, chemical, petrochemical, biochemical, metallurgical, machinery building, textile, and educational clusters.

The Rostov region: agro-industrial, fishing, electric power, tourist clusters, clusters of light manufacturing, construction supplies and agricultural machinery building.

A key role in activation of clustering processes should belong to enterprises with the high potential to elaborate and implement their own promising competitive development strategies [14, p. 12]. The process of entrepreneurial search must be given the central place in determining the directions of cluster formation in the region of the Russian Federation, development and implementation of regional cluster projects. Only entrepreneurs themselves through trial and error and experiments in the new activities can determine the potentially successful areas of business in the clusters' framework.

Therefore, it might be advisable to expand involving regional business entities in the development of cluster initiatives in the context and within the process of smart specialization of Russian regions, and to stimulate taking risks related to their innovation activities. 


\section{CONCLUSION}

Comprehension of current state and dynamics of Russian economy clustering in conditions of unstable external environment and slow economic recovery allows making the following concluding remarks.

A multi-level clusterization policy aimed at increasing the competitiveness of regions and ensuring economic growth through the new forms of the market organization of the firms' interaction in manufacturing and promoting final goods of the new generations should become an important component of the strategies for social and economic development of Russian regions.

The state support for the formation of innovative territorial clusters of national and global importance is crucial for Russian regions as it ensures imports substitution, expending exports, diversification of production based on the use of high technologies and promotion of new products on the domestic and foreign markets.

Clusters formation processes in the regional and local municipalities, which allow developing and processing local industrial resources and agricultural raw materials, could become a significant reserve for the development of Russian regions. Such clusters are vital for financial sustainability and security of rural municipalities, job creation, human capital attraction and fastening in the countryside.

Accordingly, it becomes essential to develop the multilevel network of clusters linked by the transactional infrastructure and the logistics centers system in order to increase the share of value added in the GRP, overcome the commodity dependence of Russian economy, expand the scale of modernization on the basis of vertical cross-sectoral integration, inter-farm cooperation and public-private partnership mechanisms.

It seems advisable as well to form a cellular model of regional clusterization that reflects the functional and generic links between clusters and their entries to the national and global markets (goods flows considering their scale and intensity).

Systemic development of clusters in Russian regions should become a strategic component of their smart specialization, which stimulates the growth of innovative activity in the regions, the development of cluster projects and intraregional, interregional and international cooperation to ensure their effective implementation.

\section{Acknowledgment}

The study was conducted with the financial support of the Russian Foundation for Basic Research, project No. 16-02-
00591- OGN "State policy of the Russian Federation in the sphere of nanoindustry in an unfavorable external environment conditions".

\section{References}

[1] O. Inshakov, "Inconsistency of theory, policy and practice of clustering in modern Russia," International Journal of Trade and Global Markets, vol. 10, No. 2/3, pp. 198-206, 2017. DOI: 10.1504/IJTGM.2017.10006606

[2] The Global Competitiveness Reports (2008-2017). Geneva: World Economic Forum, 2008, ... 2017.

[3] Industrial clusters of Russia - 2016: Industry overview. Moscow: Association of Clusters and Technoparks; RIA "FederalPress", 2017.

[4] A. O. Inshakova, A. I. Goncharov, M. V. Sevostyanov, "Institutional Ambiguity of Regulation of Possessory Relations in Modern Russia", in Overcoming Uncertainty of Institutional Environment as a Tool of Global Crisis Management, 2017, Edition Number 1, pp. 207-212.

[5] Ranking of innovative development of Subjects of the Russian Federation. Issue 5, G. I. Abdrakhmanova, P. D. Bakhtin, L. M. Gokhberg and others; Ed. L.M. Gokhberg; National Research University Higher school of Economics. Moscow: HSE, 2017.

[6] Ranking of innovative regions of Russia: version 2016. Moscow: Association of Innovative Regions of Russia, 2017.

[7] Scientific and technological infrastructure of the Russian Federation. URL: http://ckp-rf.ru/.

[8] O. V. Kostenko, "Agro-industrial clusters of Russia - an idea or reality?", Economics: Yesterday, Today and Tomorrow, 2016, № 4, pp. 35-46.

[9] V. V. Pechatkin, "Methods of assessment and analysis of the potential clustering of regional economy", Economic analysis: theory and practice, 2010, № 28 (193), pp. 42-48.

[10] Regions of Russia. Socio-economic indicators. 2017: Statistical compilation. M.: Rosstat, 2017.

[11] Distribution of organizations by type of economic activity (according to the state registration data). Volgogradstat, 2018. URL:http://volgastat.gks.ru/wps/wcm/connect/rosstat ts/volgastat/resour ces/45bcd280442e54bdac89affa17e1e317/Распределение+организаци й+по+видам+экономической+деятельности_23012018.htm.

[12] The industry of the Volgograd region. Prospects and directions of development. Committee of Industry and Trade of the Volgograd Region. http://minpromtorg.gov.ru/common/upload/files/docs/Volgogradskaya_o blast. Prespektivy i napravleniya razvitiya.pdf.

[13] Report on Human Development in the Russian Federation. Environmental priorities for Russia. Moscow: Analytical Center under the Government of the Russian Federation, 2017.

[14] Guide to Research and Innovation Strategies for Smart Specializations (RIS 3), Dominique Foray et al. European Commission, May 2012. URL:

http://ec.europa.eu/regional_policy/sources/docgener/presenta/smart_spe cialisation/smart ris3 2012.pdf.

[15] A. O. Inshakova, A. I. Goncharov, O. P. Kazachenok, and S. Y. Kochetkova, "Syndicated lending: intensification of transactions and development of legal regulation in modern Russia", Journal of Advanced Research in Law and Economics, 2017, Volume VIII, № 3(25), pp. 838-842. 